\title{
Cracking the riddle of dedifferentiated liposarcoma: is EV-MDM2 a key?
}

\author{
Lucia Casadei ${ }^{1,2}$, Raphael E. Pollock ${ }^{1,2}$ \\ ${ }^{1}$ The James Comprehensive Cancer Center, The Ohio State University, Columbus, Ohio, USA \\ ${ }^{2}$ Department of Surgery, Division of Surgical Oncology, The Ohio State University Wexner Medical Center, Columbus, Ohio, \\ USA
}

Correspondence to: Lucia Casadei, email: Iucia.casadei@osumc.edu

\author{
Raphael E. Pollock, raphael.pollock@osumc.edu
}

Keywords: dedifferentiated liposarcoma; extracellular vesicles; MDM2; MMP2; tumor microenvironment

Received: December 11,2019 Accepted: January 09, $2020 \quad$ Published: February 01, 2020

Copyright: Casadei and Pollock. This is an open-access article distributed under the terms of the Creative Commons Attribution License 3.0 (CC BY 3.0), which permits unrestricted use, distribution, and reproduction in any medium, provided the original author and source are credited.

\section{ABSTRACT}

Dedifferentiated liposarcoma (DDLPS) is molecularly characterized by wt p53 and MDM2 gene amplification causing MDM2 protein over-production, the key oncogenic process in DDLPS. Commonly located in fat-bearing retroperitoneal areas, almost $60 \%$ of DDLPS patients undergo multifocal recurrence, typically amenable to palliative treatment only, and occasionally develop distant metastasis. These factors lead to an abysmal $10 \% 10$ year overall survival rate.

Tumor cell-derived extracellular vesicles (EVs) can facilitate loco-regional malignancy dissemination by depositing molecular factors that participate in the development of pre-metastatic niches for tumor cell implantation and growth. High number of MDM2 DNA molecules was identified within EVs from DDLPS patient serum (ROC vs normal; 0.95) as well as from DDLPS cell lines. This MDM2 DNA could be transferred to preadipocytes ( $\mathrm{P}-\mathrm{a})$, a major and ubiquitous cellular component of the DDLPS tumor microenvironment (TME), with subsequent $P$-a production of matrix metalloproteinase 2 (MMP2), a critical component in the metastatic cascade. From here the hypothesis that the DDLPS microenvironment (specifically P-a cells) may participate in DDLPS recurrence events.

Since multifocal loco-regional DDLPS spreading is the main cause of the remarkably high lethality of this disease, a better understanding of the underlying oncogenic processes and their regulatory mechanisms is essential to improve the outcome of this devastating disease.

\section{INTRODUCTION}

Dedifferentiated liposarcoma (DDLPS) of the retroperitoneum kills patients due to incontrollable locoregional recurrence. In as many as $60 \%$ of patients such recurrences are multi-focal and are usually beyond meaningful therapeutic interventions other than palliation; hence an overall DDLPS survival rate of only $10-20 \%$ at 10 years [1-3].

The study of DDLPS molecular mechanisms has established the prevalence of 12q13-15 chromosomal amplification as the most common molecular derangement in this disease. As a result of this amplification, overexpression of CDK4, JUN and MDM2 occurs [4]. The latter is observed in almost $100 \%$ of DDLPS patients; MDM2 overexpression represses p53-induced transcription and also triggers ubiquitination and subsequent degradation of $\mathrm{p} 53$, the guardian of the genome. These processes contribute to tumor development in that enhanced MDM2 leads to impaired p53 suppression of tumor growth and impaired p53 promotion of apoptosis. While these molecular mechanisms underlying DDLPS pathogenesis has been previously described [5], the processes driving DDLPS recurrence, especially multi-focal recurrence, are yet to be determined.

Given the potential therapeutic implications, we have been interested in possible mechanisms of DDLPS recurrence and are considering the role of the DDLPS microenvironment. 
The DDLPS microenvironment includes macrophages, adipocytes, and preadipocytes (P-a), all of which are likewise prevalent in the fat-bearing retroperitoneal compartment, the most common DDLPS location $[6,7]$.

We have discovered that DDLPS extrude extracellular vesicles (EVs), and they are involved in intercellular communication between DDLPS and recipient microenvironment cells such as P-a [8]. This interaction can result in transfer of protein, nucleic acids, and other biologically active molecules, and may contribute to tumor progression [8].

DDLPS EVs are transferred to recipient microenvironment P-a cells [8]. When exposed to DDLPS EVs, P-a can exhibit some phenotypic characteristics of cancer cells; e.g., enhanced proliferation and migration compared to cells incubated with EV-depleted medium.

We discovered that $M D M 2$ DNA, amplified in nearly $100 \%$ of DDLPS, is transferred from DDLPS cells via EVs to P-a cells. P-a that are exposed to DDLPS EVs undergo a reduction of p53 and p21 levels (Figure 1). When P-a were incubated with EVs in the presence of the MDM2 inhibitor SAR405838 (Sanofi-Aventis), the rate of proliferation and migration of recipient cells was significantly impaired compared to $\mathrm{P}$-a treated with $\mathrm{EV}$ alone.

To date, transfer of material from EVs to recipient cells has been well documented for mRNAs, miRNAs, and proteins [9-12] but only rarely for DNA [13-15], especially regarding transfer of functional DNA [16]. We suggest the possibility that EVs can transfer functional DNA from host to recipient cells, perhaps serving in a manner analogous to a viral vector. If this hypothesis is correct, it would suggest many new questions about the mechanisms involved in such transfer, translation, and consequent transduction of protein from donor cell EVs to host cells.

Although previously not considered, the DDLPS microenvironment (specifically $\mathrm{P}$-a cells) may participate in DDLPS recurrence events. Extracellular matrix degradation is one of the key initial events underlying tumor cell dissemination and recurrence [17]. Responsible factors include metalloproteinases such as MMP2; these have been shown to promote cancer progression due to their degrading basement membrane components and collagen break down into peptides that act as chemoattractants for circulating tumor cells [18]. In the context of liposarcoma, MMP2 has been correlated with cell invasiveness, metastasis, and grade $[19,20]$. We found that $M D M 2$ DNA transfer from DDLPS to P-a induces activation of P-a MMP2 (Figure 1). In keeping with our hypothesis, given the prevalence of $\mathrm{P}-\mathrm{a}$ in the DDLPS microenvironment and throughout the retroperitoneum, stimulated P-a MMP2

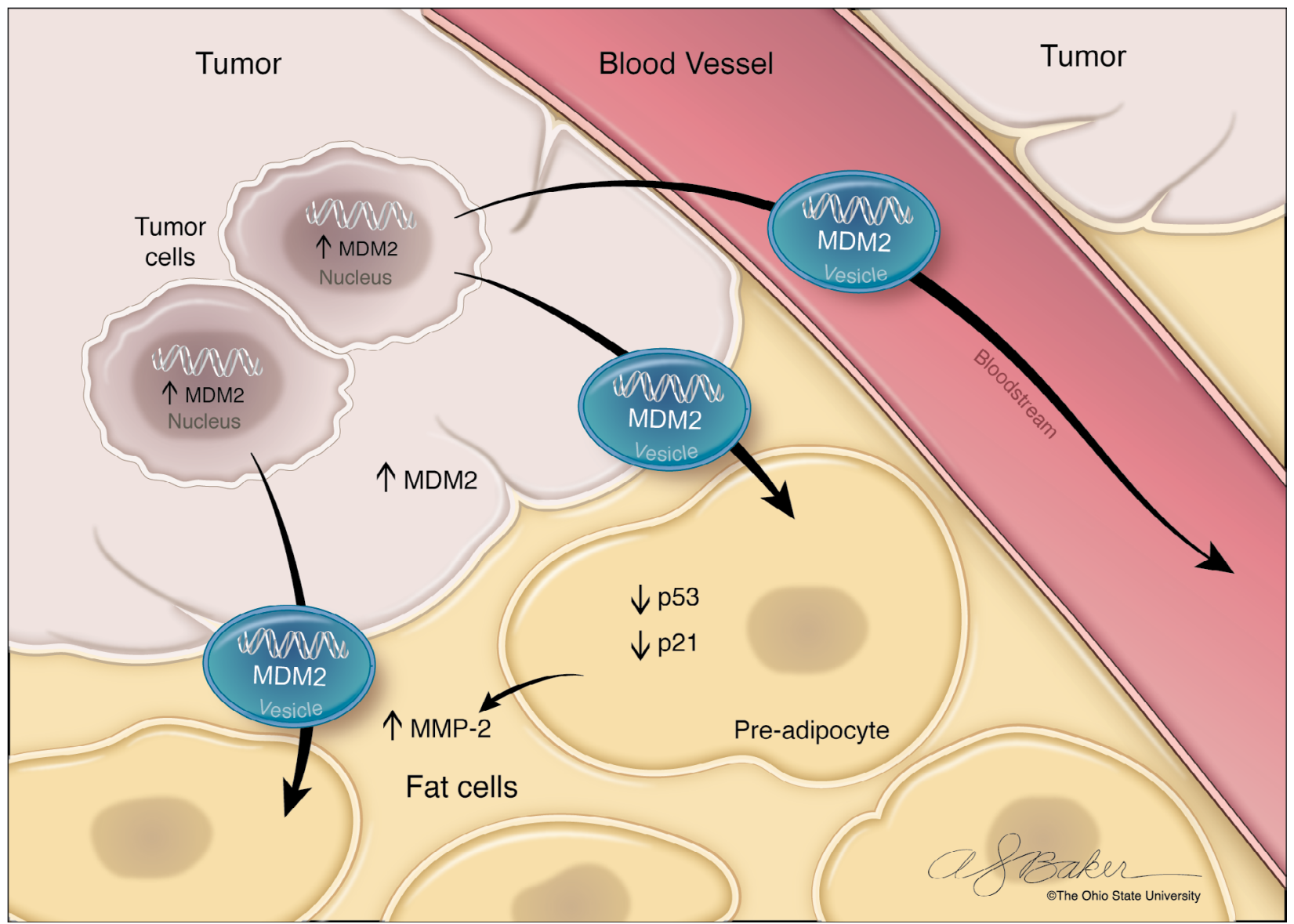

Figure 1: EV- dependent MDM2-DNA transfer from DDLPS to recipient P-a. We have demonstrated high levels of $M D M 2$ DNA in EVs derived from both DDLPS cell lines and also DDLPS patient serum samples. DDLPS EV MDM2 can be transferred to recipient $\mathrm{P}$-a where they promote release of active MMP2, thereby possibly contributing to subsequent multifocal loco-regional multifocal DDLPS dissemination and recurrence. 
activity may be pertinent to the extremely high rate of DDLPS multifocal recurrence.

The need for prognostic biomarkers in a disease for which there are none is also apparent. Amplification of MDM2 DNA is readily demonstrable by fluorescence in situ hybridization (FISH) and it commonly used to diagnose DDLPS [21]. We have shown that circulating EV-MDM2 DNA copy number can effectively discriminate DDLPS patients versus normal controls by Receiving Operating Characteristic curve analysis [8]. In these studies, the area under the curve (AUC) for MDM2 was $95.8 \%$ with a $95 \%$ confidence interval, indicating robust separation of DDLPS patients from healthy controls. We are now conducting a clinical trial to more firmly establish EV MDM2 DNA copy number as a useful DDLPS biomarker.

The underlying regulatory mechanisms of this novel MDM2:MMP2 interactions are now the focus of our ongoing studies. We are considering whether the regulation of MMP2 by MDM2 might happen at the DNA, mRNA and/or protein level, and whether this regulation might occur in either a direct or perhaps indirect fashion involving other intermediate proteins such as TIMPs. In addition, the possible contribution of others MMPs (such as MMP9) to these processes is also currently being explored. Cracking the riddle of this rare and devastating disease is both a challenge and an imperative; please join us!

\section{CONFLICTS OF INTEREST}

The authors declares no potential conflicts of interest.

\section{REFERENCES}

1. Anaya DA, Lahat G, Liu J, Xing Y, Cormier JN, Pisters PW, Lev DC, Pollock RE. Multifocality in retroperitoneal sarcoma: a prognostic factor critical to surgical decisionmaking. Ann Surg. 2009; 249:137-42. https://doi. org/10.1097/SLA.0b013e3181928f2f. PMID:19106689

2. Bill KL, Casadei L, Prudner BC, Iwenofu H, Strohecker AM, Pollock RE. Liposarcoma: molecular targets and therapeutic implications. Cell Mol Life Sci. 2016; 73:3711-18. https://doi.org/10.1007/s00018-016-2266-2. PMID:27173057

3. Tseng WW, Somaiah N, Lazar AJ, Lev DC, Pollock RE. Novel systemic therapies in advanced liposarcoma: a review of recent clinical trial results. Cancers (Basel). 2013; 5:529-49. https://doi.org/10.3390/cancers5020529. PMID:24216990

4. Guan Z, Yu X, Wang H, Wang H, Zhang J, Li G, Cao J, Teng L. Advances in the targeted therapy of liposarcoma. OncoTargets Ther. 2015; 8:125-36. https://doi.org/10.2147/ OTT.S72722. PMID:25609980

5. Crago AM, Singer S. Clinical and molecular approaches to well differentiated and dedifferentiated liposarcoma. Curr
Opin Oncol. 2011; 23:373-78. https://doi.org/10.1097/ CCO.0b013e32834796e6. PMID:21552124

6. Loewenstein S, Lubezky N, Nizri E, Zemel M, Levin Y, Savidor A, Sher O, Klausner JM, Lahat G. Adipose-Induced Retroperitoneal Soft Tissue Sarcoma Tumorigenesis: A Potential Crosstalk between Sarcoma and Fat Cells. Mol Cancer Res. 2016; 14:1254-65. https://doi. org/10.1158/1541-7786.MCR-16-0131. PMID:27621268

7. Casadei L, Calore F, Creighton CJ, Guescini M, Batte K, Iwenofu OH, Zewdu A, Braggio DA, Bill KL, Fadda P, Lovat F, Lopez G, Gasparini P, et al. Exosome-Derived miR-25-3p and miR-92a-3p Stimulate Liposarcoma Progression. Cancer Res. 2017; 77:3846-56. https://doi. org/10.1158/0008-5472.CAN-16-2984. PMID:28588009

8. Casadei L, Calore F, Braggio DA, Zewdu A, Deshmukh AA, Fadda P, Lopez G, Wabitsch M, Song C, Leight JL, Grignol VP, Lev D, Croce CM, Pollock RE. MDM2 Derived from Dedifferentiated Liposarcoma Extracellular Vesicles Induces MMP2 Production from Preadipocytes. Cancer Res. 2019; 79:4911-22. https://doi.org/10.1158/0008-5472. CAN-19-0203. PMID:31387924

9. Al-Nedawi K, Meehan B, Kerbel RS, Allison AC, Rak J. Endothelial expression of autocrine VEGF upon the uptake of tumor-derived microvesicles containing oncogenic EGFR. Proc Natl Acad Sci USA. 2009; 106:3794-99. https://doi.org/10.1073/pnas.0804543106. PMID:19234131

10. Antonyak MA, Li B, Boroughs LK, Johnson JL, Druso JE, Bryant KL, Holowka DA, Cerione RA. Cancer cellderived microvesicles induce transformation by transferring tissue transglutaminase and fibronectin to recipient cells. Proc Natl Acad Sci USA. 2011; 108:4852-57. https://doi. org/10.1073/pnas.1017667108. PMID:21368175

11. Lindoso RS, Collino F, Camussi G. Extracellular vesicles derived from renal cancer stem cells induce a protumorigenic phenotype in mesenchymal stromal cells. Oncotarget. 2015; 6:7959-69. https://doi.org/10.18632/ oncotarget.3503. PMID:25797265

12. Paggetti J, Haderk F, Seiffert M, Janji B, Distler U, Ammerlaan W, Kim YJ, Adam J, Lichter P, Solary E, Berchem G, Moussay E. Exosomes released by chronic lymphocytic leukemia cells induce the transition of stromal cells into cancer-associated fibroblasts. Blood. 2015; 126:1106-17. https://doi.org/10.1182/ blood-2014-12-618025. PMID:26100252

13. Balaj L, Lessard R, Dai L, Cho YJ, Pomeroy SL, Breakefield XO, Skog J. Tumour microvesicles contain retrotransposon elements and amplified oncogene sequences. Nat Commun. 2011; 2:180. https://doi. org/10.1038/ncomms1180. PMID:21285958

14. Cai J, Han Y, Ren H, Chen C, He D, Zhou L, Eisner GM, Asico LD, Jose PA, Zeng C. Extracellular vesicle-mediated transfer of donor genomic DNA to recipient cells is a novel mechanism for genetic influence between cells. J Mol Cell Biol. 2013; 5:227-38. https://doi.org/10.1093/jmcb/mjt011. PMID:23580760 
15. Fischer S, Cornils K, Speiseder T, Badbaran A, Reimer $\mathrm{R}$, Indenbirken D, Grundhoff A, Brunswig-Spickenheier B, Alawi M, Lange C. Indication of Horizontal DNA Gene Transfer by Extracellular Vesicles. PLoS One. 2016; 11:e0163665. https://doi.org/10.1371/journal. pone. 0163665 . PMID:27684368

16. Waldenström A, Gennebäck N, Hellman U, Ronquist G. Cardiomyocyte microvesicles contain DNA/RNA and convey biological messages to target cells. PLoS One. 2012; 7:e34653. https://doi.org/10.1371/journal.pone.0034653. PMID:22506041

17. Poltavets V, Kochetkova M, Pitson SM, Samuel MS. The Role of the Extracellular Matrix and Its Molecular and Cellular Regulators in Cancer Cell Plasticity. Front Oncol. 2018; 8:431. https://doi.org/10.3389/fonc.2018.00431. PMID:30356678

18. Kessenbrock K, Plaks V, Werb Z. Matrix metalloproteinases: regulators of the tumor microenvironment. Cell. 2010; 141:52-67. https://doi.org/10.1016/j.cell.2010.03.015. PMID:20371345

19. Benassi MS, Gamberi G, Magagnoli G, Molendini L, Ragazzini P, Merli M, Chiesa F, Balladelli A, Manfrini M, Bertoni F, Mercuri M, Picci P. Metalloproteinase expression and prognosis in soft tissue sarcomas. Ann Oncol. 2001; 12:75-80. https://doi.org/10.1023/A:1008318614461. PMID:11249053

20. Pazzaglia L, Ponticelli F, Magagnoli G, Magagnoli G, Gamberi G, Ragazzini P, Balladelli A, Picci P, Benassi M. Activation of metalloproteinases- 2 and -9 by interleukin1alpha in S100A4-positive liposarcoma cell line: correlation with cell invasiveness. Anticancer Res. 2004; 24:967-72. PMID:15161051

21. Thway K, Wang J, Swansbury J, Min T, Fisher C. Fluorescence In Situ Hybridization for MDM2 Amplification as a Routine Ancillary Diagnostic Tool for Suspected Well-Differentiated and Dedifferentiated Liposarcomas: Experience at a Tertiary Center. Sarcoma. 2015; 2015:812089. https://doi.org/10.1155/2015/812089. PMID:25810689 